\section{Good words, good food, good mind: Restoring Indigenous identities and ecologies through transformative learning}

Keith Williams a*
Special JAFSCD Issue

Indigenous Food Sovereignty in North America sponsored by

\section{Swette Center for Sustainable Food Systems} Arizona State University

First Nations Technical Institute and St Francis Xavier University

Suzanne Brant ${ }^{b}$

First Nations Technical Institute

Submitted January 9, 2019 / Revised April 1 and 16, 2019 / Accepted April 1, 2019 /

Published online October 21, 2019

Citation: Williams, K., \& Brant, S. (2019). Good words, good food, good mind: Restoring Indigenous

identities and ecologies through transformative learning. Journal of Agriculture, Food Systems, and

Community Development, 9(Suppl. 2), 131-144. https://doi.org/10.5304/jafscd.2019.09B.010

Copyright (C) 2019 by the Authors. Published by the Lyson Center for Civic Agriculture and Food Systems. Open access under CC-BY license.

\begin{abstract}
Each year, more interdisciplinary food-related programs are offered at Turtle Island colleges and universities. First Nations Technical Institute (FNTI), an Indigenous postsecondary institution located on Tyendinaga Mohawk Territory, Ontario, is in the process of developing an Indigenous food systems undergraduate degree program. This article shares our thoughts regarding education for food system transformation at FNTI. Transformative learning theory (Mezirow, 2000) presents a framework for adult learning with the potential to effect food sys-

\footnotetext{
a * Corresponding author: Keith Williams, Special Projects Advisor, First Nations Technical Institute (FNTI); and Ph.D. candidate, St. Francis Xavier University; Box 215, 1207 J Jordan Road; Canning, Nova Scotia B0P 1H0 Canada; +1-902-5827551; keithw@,fnti.net (work); x2017vpd@stfx.ca (school)

b Suzanne Brant, President, First Nations Technical Institute; 3 Old York Road; Deseronto, Ontario K0K 1X0 Canada; +1-613-396-2122; suzanneb@,fnti.net
}

tem change. Our paper examines this theory considering traditional Haudenosaunee teachings and contemporary thought. Despite the potential for food system transformation, transformative learning theory-grounded in Western thought_can not lead to a truly decolonized food system because it offers the Indigenous learner little to rebuild that which was deconstructed. Although transformative learning theory and Haudenosaunee ways of knowing are incompatible, transformative learning could help Indigenous learners to challenge implicit colonial narratives as part of the process of decolonization. Transformative learning theory may also have value for cultivating allies in non-Indigenous contexts. We are designing our Indigenous food systems program according to traditional Haudenosaunee principles such as

\section{Conflict of Interest Disclosure}

Both authors work for and are paid by First Nations Technical Institute, the organization discussed in this paper. 
ka'nikonhri:io (good mind), and we will employ talking circles, common to many Indigenous nations. We suggest that a food system pedagogy, based on traditional teachings and principles from specific Indigenous nations, is the only authentic route to a decolonized and equitable food system.

\section{Keywords}

Transformative Learning, Food Systems, Three Sisters, Collectivist, Indigenous Higher Education, Decolonization, Individualist, Relationality, Traditional Ecological Knowledge (TEK)

\section{Introduction}

This article explores the compatibility of transformative learning theory (Mezirow, 2000) with Haudenosaunee $^{1}$ ethico-onto-epistemology, the concept of inseparable relationship between doing/being/knowing (Barad, 2007; Wilson, 2008), in the context of Indigenous food system education at the postsecondary level. We are currently preparing an Indigenous food systems undergraduate degree curriculum at First Nations Technical Institute (FNTI), based in Tyendinaga Mohawk Territory, Ontario. An increasing number of interdisciplinary food systems programs are offered at Turtle Island ${ }^{2}$ colleges and universities each year (Hartle, Cole, Trepman, Chrisinger, \& Gardner, 2017). Insights gleaned during the development of our community-based Indigenous food systems degree program - to our knowledge the first of its kind on Turtle Island-can contribute to food system transformation in Haudenosaunee, other Indigenous, and mainstream contexts.

Food systems are socio-ecological in scope and operate at various, often interrelated, scales (Berkes, Colding, \& Folke, 2003). They include food production, processing, distribution, consumption, and the outcomes of those activities, which can include food security, social welfare, and the integrity of the natural environment. Food security of a given population is a fundamental function of the food system (Ericksen, 2008). Food insecurity - the opposite of food security - is defined as the lack of access to safe and nutritious foods sufficient for an active and healthy life (Food and Agriculture Organization of the United Nations [FAO], 1996). Estimates suggest that $12.0 \%$ of Canadian households were food insecure in 2014 (Tarasuk, Mitchell, \& Dachner, 2016), with Indigenous households enduring food-insecurity rates that are over double the national levels (Council of Canadian Academies, 2014; Subnath, 2017). Colonialism has drastically reduced Indigenous peoples' land base for subsistence food production and have decimated traditional knowledges, including those associated with food production and preparation (Coté, 2016). That, in turn, has yielded the high food-insecurity rates and associated unhealthy diets with epidemic levels of diabetes, high levels of cardiovascular disease, and significant mental health issues (Council of Canadian Academies, 2014).

The complexity of food systems (Foran et al., 2014), paired with the significant historical and contemporary effects of the colonial apparatus on Indigenous food systems (Coté, 2016), suggests that a nuanced decolonizing approach is required to address the layered and intersectional barriers faced by Indigenous communities in pursuit of an equitable and sustainable food system. Food system self-determination is supported by the United Nations Declaration of the Rights of Indigenous Peoples (UNDRIP), which advocates for Indigenous peoples having the right "to maintain and strengthen their own institutions, cultures and traditions, and to pursue their development in keeping with their own needs and aspirations" (United Nations, 2007, p. 2).

Postcolonial scholars have long argued that the most insidious, intractable, and damaging aspect of colonialism is the colonization of the Indigenous mind - that is, the internalization of imperial perspectives that fix notions of inferiority in the minds

\footnotetext{
${ }^{1}$ Haudenosaunee peoples (formerly called Iroquois), or people of the longhouse, are the confederacy of six First Nations-Mohawk, Cayuga, Oneida, Onondaga, Seneca, and Tuscarora — all united by a common goal to live in harmony.

2 'Turtle Island' refers to North America. This term was popularized, in English, by poet Gary Snyder in his 1974 collection Turtle Island. The name is based on the significance of turtles in the creation teachings of various Indigenous nations (including Haudenosaunee).
} 
of Indigenous people themselves (Said, 1993; Sheridan \& Longboat, 2006; wa Thiong'o, 1994). Transformative learning, with its emphasis on profound changes in perspective (Mezirow, 2000), holds promise as a tool for decolonizing the minds of Indigenous learners, preparing them to lead efforts toward self-determined food systems. The following sections outline transformative learning theory, introduce FNTI's Indigenous food systems degree program and our talking circle approach, and discuss transformative learning as a decolonizing pedagogic tool in Haudenosaunee contexts.

\section{Overview of Transformative Learning Theory}

Transformative learning is an approach to adult education that provides learners with opportunities to experience an accumulation of insights and/or a profound disorienting dilemma that, with the proper support, can lead to critical reflection on the learners' fundamental assumptions and subsequent transformation of the learners' worldview (Mezirow, 2000). Jack Mezirow described 10 phases of transformative learning through his work with women who were re-entering either the workforce or postsecondary education after a significant hiatus (Mezirow, 1991, 1994). The theory has since been amended to include an eleventh phase (see Table 1).

Mezirow (1991) suggests that people construct their world understandings at two cognitive levels, with "meaning perspectives" that comprise clusters of "meaning schemes." Meaning perspectives, also known as frames of reference, are "structures of assumptions within which one's past experience assimilates and transforms new experience" (Mezirow, 1991, p. 42). One's meaning perspective consists of habits of mind that are informed by sociolinguistic, moral-ethical, epistemic, philosophical, psychological, and aesthetic perspectives (Mezirow, 2000). Perspectives manifest as points of view that comprise clusters of meaning schemes. A meaning scheme is a "constellation of concept, belief, judgement, and feeling which shapes a particular interpretation" (Mezirow, 1994, p. 223). As Mezirow (1991) illustrates, an ethnocentric meaning perspective may lead to specific meaning schemes such as the negative racial stereotype of a specific group of people.

Critical reflection of assumptions can lead to a shift in one's meaning schemes, which can cumulatively lead to a shift in meaning perspective. Critical reflection includes both objective and subjective reframing (Mezirow, 1998). Subjective reframing involves the critical assessment of one's own assumptions, whereas objective reframing deals with the reframing of the assumptions implicit in a text or activity (Mezirow, 1998).

Critical reflection can be precipitated by an accumulation of dilemmas or a profoundly disori-

\section{Table 1. The Phases of Transformative Learning}

\begin{tabular}{|c|c|}
\hline Pha & \\
\hline 1 & A disorienting dilemma or series of dilemmas \\
\hline 2 & Self-examination with feelings of guilt or shame \\
\hline 3 & A critical assessment of epistemic, sociocultural, or psychic assumptions \\
\hline 4 & $\begin{array}{l}\text { Recognition that one's discontent and the process of transformation are shared and that others have negotiated a } \\
\text { similar change }\end{array}$ \\
\hline 5 & Exploration of options for new roles, relationships, and actions \\
\hline 6 & Planning a course of action \\
\hline 7 & Acquisition of knowledge and skills for implementing one's plans \\
\hline 8 & Provisional trying of new roles \\
\hline 9 & Renegotiating relationships and negotiating new relationships \\
\hline 10 & Building of competence and self-confidence in new roles and relationships \\
\hline 11 & A reintegration into one's life on the basis of conditions dictated by one's new perspective \\
\hline
\end{tabular}

Source: Adapted from Mezirow, 1994. 
enting dilemma that challenge existing meaning schemes or meaning perspectives (Mezirow, 1991). In this theory, the role of the transformative educator is to create an environment that is conducive to critical reflection and supportive of each of the eleven phases of transformative learning (Cranton, 2006).

Transformative learning has generated significant interest since the 1970s, resulting in hundreds of scholarly publications and dozens of books on the subject as well as an academic journal devoted to this theory, the Journal of Transformative Education (Mezirow, 2006). A limited number of papers focus on agriculture and food systems, including Davila and Dyball's (2015) paper on transformative learning as an approach to revitalizing food systems in urban Australia. Another article explores the transformative potential of a course offered by wellknown activists Vandana Shiva and Satish Kumar that "offers a physical, community-based site of resistance to the dominant industrial agri-food system" (Etmanski, 2018, p. 152). In a recently published collection, Tristan Reader and Terrol Dew Johnson (2017) describe a Tohono O'odham food system program that draws on both transformative learning and Freire's (2012) conscientization. Davila and Dyball (2015) and Etmanski (2018) draw explicitly from Mezirow's (2000) transformative learning theory. Reader and Dew Johnson (2017) do not specifically mention Mezirow's theory, although it may be implicit in their project design. Each of the aforementioned articles offers useful insights for our work at FNTI. However, only Etmanski (2018) identifies some of the cultural biases associated with transformative learning theory.

Other interesting developments include evidence that perspective transformation can be persistent (Courtenay, Merriam, \& Reeves, 1998), applicable across cultures (Merriam \& Sek Kim, 2008), modified to recognize nonhuman agency (Barrett et al., 2017), and can be inclusive of the affective domain (Dirkx, 2006; Taylor, 2007). This all suggests that transformative learning theory holds significant promise for facilitating an enduring change in our dysfunctional food system.

\section{FNTI's Indigenous Food Systems Degree Program and the Talking Circle Approach}

First Nations Technical Institute is an Indigenousrun postsecondary institute, established in 1985, situated on Tyendinaga Mohawk Territory in Ontario, Canada. FNTI offers both on-campus and in-community programming and has taught Indigenous learners from 102 of the 129 Ontario First Nations, as well as students from Indigenous communities across Canada.

The province of Ontario recently passed the Indigenous Institutes Act (the Act), effectively granting Indigenous postsecondary institutes ${ }^{3}$ the latitude to govern themselves and to offer university degrees (Indigenous Institutes Act, 2017). The Act supports Indigenous self-determination through Indigenous control of Indigenous postsecondary education, in the spirit of reconciliation and to honor the United Nations Declaration on the Rights of Indigenous Peoples, to which Canada is a signatory party (Province of Ontario, 2017). In response to this legislation, and with direction from community leaders and knowledge keepers, FNTI is developing several baccalaureate-level degree programs in key areas, one of which is Indigenous food systems. This four-year degree program, which at the time of this writing is still under development, has as its primary goal the revitalization of Indigenous identity in relation to the individual, family, community, nation, and natural and spiritual world. The Indigenous food systems degree program will support learners to first restore or strengthen their own cultural fluency and then to learn about the various dimensions of Indigenous food system revitalization (e.g., community development, ecological restoration, agricultural skills, wild food gathering), all of which are grounded in both Haudenosaunee worldviews and traditional ecological knowledge (TEK). They will also learn

\footnotetext{
3 Ontario's Indigenous Institutes are similar to Native American Tribal Colleges in the United States. There are currently nine Indigenous-governed and -operated postsecondary institutes in Ontario that serve the education and training needs of the communities in which they are based. More information about Ontario's Indigenous institutes can be found at https://news.ontario.ca/maesd/en/2017/11/ontario-breaking-ground-in-indigenous-postsecondary-education.html
} 
from Western and other cultural food system approaches where relevant. FNTI's curricular approach for the Indigenous food systems degree program is very different from mainstream approaches in agriculture and food systems-related higher education. Rather than surveying the key scientific disciplines that inform or support a mainstream undergraduate science degree, the FNTI curricular approach uses the first two years of this degree to restore or strengthen the learner's cultural identity, with a special focus on cultural elements related to the food system (e.g., food and ceremony, food and expressive culture, Indigenous traditional ecological knowledge). This two-year immersion in Indigenous culture will be applied by the students in specific food-related courses in years three and four, such as greenhouse production and management, Indigenous gathered foods and nutrition, soil and water management, and sustainable plant production. FNTI students come from a range of Indigenous cultural backgrounds, such as Haudenosaunee, Anishinaabe, and Cree. The hiring of staff based on their cultural fluency and the of leveraging student understandings for group learning allow for program delivery in culturally mixed classrooms and classrooms with one predominant culture. In addition, we are exploring opportunities to formally enhance the Anishinaabe content of our program curriculum.

The Indigenous food system degree program will employ FNTI's pedagogic approach, including use of the talking circle. Faculty members are encouraged to start and finish each day with a talking circle. Talking circles are thought to have originated as a form of parliamentary procedure with Plains Indigenous groups in what is now Canada and the United States (Mehl-Madrona \& Mainguy, 2014). Talking circles, and the related healing circles, sharing circles, and peacemaking circles have found broad applicability in fields as diverse as wildlife conservation (Simmons, Bayha, Beaulieu, Gladu, \& Manseau, 2012), healthcare (Rothe, Ozegovic, \& Carroll, 2009), education (Winters, n.d.), restorative justice, and by feminist community activists (Umbreit, 2003).

The circle form is viewed as sacred across a number of Indigenous cultures (Running Wolf \& Rickard, 2003). It signifies and honors the interconnectedness of all things by reflecting form and process from the natural world, such as bird nests, the pattern in which animals mark their territories, and the moon and sun and their trajectories across the sky (Mehl-Madrona \& Mainguy, 2014; Ontario Ministry of Education, 2009; Wilber, Wilbur, Tlanusta Garrett, \& Yuhas, 2001).

The FNTI talking circle brings together participants and a facilitator-usually the instructor-in a nonhierarchical activity in which everyone can share their experiences, without interruption, in a supportive, nonjudgmental and nonconfrontational manner (Fleishhacker, Vu, Ries, \& McPhail, 2011). Talking circles are often used to support healing and transformational experiences for participants (Kholghi, Bartlett, Phillips, Salsberg, McComber, \& Macaulay, 2018; Lowe \& Wimbish-Cirilo, 2016; Wilbur et al., 2001). At FNTI, students bring their 'whole person' to the circle. So, although the opening focus may be on curricular material or another aspect of the educational experience, all aspects of the individual — heart, mind, body, and spirit — are shared (Nabigon, Hagey, Webster, \& MacKay, 1999). Talking circles support personal transformation, which complements, and is complemented by, the academic learning that takes places at FNTI. The talking circle approach will be an important component of the new Indigenous food systems degree program. The talking circle is one of a suite of approaches that will facilitate learners' rediscovery of their culture and will help them make sense of their lives and future aspirations in reference to the Indigenous food systems degree curriculum and more.

\section{Transformative Learning Theory and the Decolonization of Indigenous Food Systems} From our experience and based on the words of students and graduates from FNTIs programs, our pedagogic approach can facilitate profound personal growth for our learners. ${ }^{4}$ This section explores the question: how can transformative learning theory contribute to education for a decolonized food system?

4 Student testimonials regarding their experiences at FNTI can be found at https://fnti.net/testimonials-new 
Transformative learning results in a profound perspective change caused by one or more disorienting dilemmas (Mezirow, 2000). Presumably, the outcome of transformative learning is dependent upon the values, personal history, and other characteristics of the individual undergoing a transformation and the nature of the disorienting dilemma(s) that they undergo. We suggest that the resultant transformation is also influenced by the models of change specific to the cultural context in which the learning is taking place. These two classes of interrelated factors - the individual and the cultural/societal - influence both the way that transformative learning is enacted and the outcome of that learning. We examine both below.

The intergenerational trauma resulting from residential school, language loss, and other forms of cultural genocide poses significant barriers to success for Indigenous learners in postsecondary institutions (Battiste, 2016; Reader \& Dew Johnson, 2017). Transformative learning theory is culture-bound (Merriam \& Ntseane, 2008) and could serve, at worst, to reinforce the structural, dominant-culture mores that actively erode Indigenous cultural institutions. For example, the role of the teacher in transformative learning environments is to model "the critically reflective role expected of learners. Ideally, the facilitator ... become(s) a colearner by progressively transferring her leadership to the group as it becomes more selfdirective" (Mezirow, 1997, p. 11). While use of the word 'colearner' in the above quotation suggests a less hierarchical approach, there is a lack of published work indicating that educators have the capacity to be transformed, themselves, by the transformative experiences that they facilitate in the classroom, which suggests an implicit hierarchy.

During talking circles, such as those that take place in FNTI classrooms, the instructor models the openness and vulnerability necessary for group transformation as an active participant (Winters, n.d.). This serves several purposes, one of which is to affirm the nonhierarchical approach inherent in traditional models of Indigenous education. Despite gesturing towards colearning, transformative learning theory has not yet fully articulated a nonhierarchical position for the educator/ facilitator. Incorporating transformative learning theory into Indigenous classrooms, in which the instructor assumes a higher and/or separate status than students, reinforces Western values that are antithetical to Indigenous approaches. To take this example further, an Indigenous approach to farming and food gathering positions humans in relation with rather than separate from the natural world (Salmón, 2012). Educational models, in food systems classrooms, that reinforce hierarchical constructs could plausibly serve to reinforce the Western human/nature dichotomy that, arguably, is associated with the dispossession of Indigenous people from the land, loss of TEK, and has contributed to the current ecological crisis (Cajete, 2000).

Haudenosaunee culture, and Indigenous cultures in general, can be described in collectivist terms (Mohawk \& Barreiro, 2010; Morcom, 2017), in contrast to Western or European cultures, which are considered individualistic (Hofstede, 1980). Individualistic societies are typically contractual regarding social relations, with a focus on achieving status and reaching personal goals at the expense of the social (Oyserman, Coon, \& Kemmelmeier, 2002; Schwartz, 1990). Collectivist societies are described as having diffuse mutual obligations in which the individual is recognized as part of the group (Schwartz, 1990). Oyserman et al. (2002) identify salient distinctions between collectivist and individualist societies in terms of "self-concept, well-being, attribution style, and relationality" (p. 5). Collectivist societies, according to several authors, are more diverse in terms of "values, attitudes, and behaviors" (Oyserman et al., 2002, p. 5) than individualistic societies (Hui, 1988; Triandis, 1995). For example, regarding relationality in collectivist contexts, Chen, Brocker, and Katz (1998) suggested that in-group favoritism was due to internalized value systems in Chinese students. Yamagishi (1988) in Oyserman et al. (2002) observed that Japanese business students left poorly performing groups despite the expectation that they would exhibit a higher level of in-group favoritism. The aforementioned article concluded that "Japanese cooperation is not due to internalized collectivist values but instead is the result of structural monitoring and sanctioning of non- 
contributing free riders" (Oyserman et al., 2002, p. 38). Understanding the motivations of collectivist behavior in Haudenosaunee and other Indigenous cultures would help to better align decolonizing food system educational initiatives with the culturespecific motivations underpinning Indigenous relationality. The following paragraph discusses relationality in Western and Indigenous cultural contexts regarding transformative learning and food system decolonization.

Transformative learning theory has, as a goal, enhanced learner autonomy (Mezirow, 1997). For Mezirow, "thinking as an autonomous and responsible agent is essential for full citizenship in democracy and for moral decision making in situations of rapid change" (1997, p. 7). Transformative learning theory's focus on the individual rather than the collective is at odds with Indigenous relationality. This relationality is a fundamental aspect of Indigenous worldviews and consists of the multiple relationships (and attendant responsibilities) that exist within and between humans and other living and nonliving entities (Weber-Pillwax, 2001). Indigenous scholar Shawn Wilson $(2001,2008)$ contrasts Western research paradigms, in which the researcher is accountable to standards of ethics, validity, and credibility established by the scholarly community, with Indigenous approaches to research "relational accountability or being accountable to all my relations" (Wilson, 2001, p. 177). The relational ethical stance described by Wilson (2008) is fundamentally at odds with positivist Western conceptions of scholarly activity as value-neutral. Oyserman et al. (2002) describe relationality in individualistic cultures (e.g., mainstream North America and Europe) as a cost-benefit calculation that may result in individuals "leaving relationships and groups when the cost of participation exceeds the benefits and creating new relationships as personal goals shift" (p. 5). In the same paper, relationships in collectivist societies are identified as being more fixed and stable, with "in-group exchanges based on equality or even generosity principles" (p. 5). Following Oyserman et al.'s (2002) description, transformation is likely a group endeavor in collective societies (e.g., via talking circles). The tension between Indigenous relationality and Western cultural concepts that situate human- kind-specifically European, male, heterosexual humans - as the only viable 'subject' (Butler, 2004; Culhane, 1998) contributes significantly to the continued suppression and even erasure of Indigenous identity as exemplified by myriad assimilationist policies (Coulthard, 2014). Supporting, and in some cases restoring, Indigenous relationality is critical for decolonized self-determination in the food system and in other spheres, but neither supporting nor restoring Indigenous relationality are consistent with the individualistic premises of Western systems of thought.

Haudenosaunee culture is dynamic, despite early conceptions of Indigenous culture as monolithic and unchanging (Antone, 2013; Mohawk \& Barreiro, 2010). Long before European contact, the Kaianerkó:wa (Great Law of Peace) brought together disparate nations under the Haudenosaunee confederacy, which later served as a model for the United States Constitution (Schaaf, 1988). The Kariwiyo (which translates as "Good Word"), also known as the Handsome Lake Code, was received by the Seneca prophet Handsome Lake in 1799 from four spirits while he was on his deathbed. He recovered and shared the revealed message, which provided the Haudenosaunee with guidance for how to continue being Haudenosaunee, in spite of colonial invasion and acculturation (Antone, 2013; Johansen \& Mann, 2000). The Kariwiyo reinforced the importance of the Three Sisters (corn, beans, and squash) polyculture system as critical to Haudenosaunee identity and reframed gender roles around agriculture so that men could participate more in what was once a largely female domain (Antone, 2013). In more recent times, Haudenosaunee culture has evidenced similar fortitude in the face of significant challenges exemplified by the diplomatic role of Haudenosaunee leaders in establishing processes for the recognition of Indigenous rights at the United Nations (Akwesasne Notes, 2005); the work of the Akwesasne Task force on the Environment, which has successfully navigated in both the world of Western science and traditional knowledge to effect positive environmental change for the Indigenous community (Santiago-Rivera, Morse, Hunt, \& Lickers, 1998); and the Iroquois White Corn Project (Dion-Buffalo \& Mohawk, 1999), which 
played a key role in revitalizing the use and cultivation of traditional white corn in the broader Haudenosaunee community.

As the above examples demonstrate, change, adaptation, and persistence are central to Haudenosaunee culture. Traditional conceptions of transformative change can be drawn from the original teachings of the Kaianerkó:wa, such as the principle of ka'nikonhri:io, which can be translated as the 'good mind' which "occurs when the people put their minds and emotions in harmony with the flow of the universe" (Mohawk \& Barreiro, 2010, p. 33). The 'good mind' confers the ability to make a sound judgment for the welfare of the broader Haudenosaunee society. The 'good mind' is necessary for the enactment of other Haudenosaunee principles and is a precondition for becoming Onkwehonwe, a word that means original people. Onkwehonwe also connotes the unassimilated, oldgrowth mind, a mind that is inseparable from territory (Sheridan \& Longboat, 2006). Sheridan and Longboat (2006) importantly assert that "only with restored identities can we know when restored ecologies have reestablished their authenticity" ( $p$. 367).

Oneida scholar Robert Antone (2013) prepared a curricular approach to transformational learning based on the Seven Spans paradigm from the Kaianerkó:wa, which refers to "the quality of person one has to be to be a leader" (p. 45). Antone (2013) shares that, according to the Great Law of Peace, seven spans of skin are necessary to be a good leader, and those seven spans result from "journey[ing] through seven circles of life experience" (p. 51). A teaching is passed on for each circle of life experience, and these teachings contribute to the development of the 'good mind.' Antone's (2013) approach to transformational learning is based on lessons from the seven life stages, all of which contribute to decolonization and restoration of the ka'nikonhri:io. One example he shares involves teaching about growing corn: "for a Haudenosaunee agriculturalist, it is not simply about farming but about the wholeness of one's relationship to the land, culture, teachings, ceremony, and spirit" (p. 190). The Three Sisters are critical as traditional food sources and are essential for ceremonial life. They provide spiritual and physical sustenance, and connect the Haudenosaunee agriculturalist with the cosmos, with each other, and with the natural world (Antone, 2013). Antone suggests bundling this knowledge to "build self, family, clan, and community, which, in turn, builds nation" (p. 190).

At its best, transformative learning theory could provide the learner with critical tools to actively question assumptions implicit in Western culture narratives, such as the primacy of the scientific method as a way of knowing, the hierarchical relationship to the natural world, patriarchal gender roles, and more. The questioning of colonizing narratives is an important aspect of decolonization; however, transformative learning theory and other Western cultural constructs offer the Indigenous learner little to rebuild that which was deconstructed.

Following Antone (2013) and Sheridan and Longboat (2006), we suggest that authentic decolonization can only happen through the restoration of Haudenosaunee systems of thought such as the ka'nikonhri:io. Transformative learning theory (Mezirow, 2000) is inherently Western and as such will not yield the decolonized food systems advocated for by Indigenous food sovereigntists, thinkers, and activists. Despite this, there could be a role for transformative learning theory in Indigenous food system education contexts. Critical reflection and disorienting dilemmas can be useful ways for Indigenous learners, especially those without a strong Indigenous cultural background, to interrogate the impacts of acculturation on Indigenous food systems. Transformative learning can be used up to and including phase four of the transformative learning process, which involves recognizing that other people have faced similar challenges and have undergone personal transformation (Mezirow, 1994). Phases five through eleven require learners to reconstruct the meaning perspectives that were challenged during the first four phases of the transformative learning process. At this juncture, a curriculum based on Haudenosaunee principles is essential for decolonization; for reconstructing learners' Haudenosaunee mindset rather than recolonizing the learners with Western cultural norms. Phase five through eleven must be informed by Haudenosaunee concepts such as 
ka'nikonhri:io and would ideally occur in group learning environments to foreclose the reproduction of Western cultural norms. Phases five through eleven, like phases one through four, follow a logical sequence and rely heavily on rationality and individualism - in the form of critical selfreflection (Mezirow, 1998) - as the engine of transformative change. In fact, Mezirow (2009) states that "transformative learning may be understood as the epistemology of how adults learn to reason for themselves" (p. 23). We do not deny the importance of rational thought for personal development and transformation; however, we recognize and celebrate the role of other ways of knowing that are either excluded from, or remain invisibly implicit in, the transformation occurring via Mezirow's eleven phases. Indigenous ways of knowing encompass more than rationality and can include empirical, intuitive, spiritual, and revelatory aspects, traditional teachings, and generally involve a communal construction of knowledge (Castellano, 2000; Luarkie, 2017; Wilson, 2008). Philosophical orientations, such as Indigenous epistemologies, that encompass multiple ways of knowing that are rooted in territorial gestural meaning (Sheridan \& Longboat, 2006; Zwicky, 2014) offer the best hope to profoundly transform the broken relationship between humans, the food system, and the rest of the natural world by reviving learners' desire and ability to attend to the "circumstances of being alive in the world, the dependencies, cultural and physical, animate and inanimate, that are inseparable from human existence in the world" (Zwicky, 2014, p. 142).

A transformative learning approach to food systems education, based on culture-specific principles, is critical for decolonizing Indigenous food systems. As several authors point out (Hui, 1988; Oyserman et al., 2002; Triandis, 1995), collectivisttype cultures exhibit far greater diversity in the ways that collectivism manifests, compared with individualist-type cultures. This suggests that transformative learning theory cannot simply be adapted to all collectivist cultures and then applied across the world. Neither can transformative learning be adapted for 'Indigenous' contexts and be applicable across the great diversity of cultures native to
Turtle Island. Food system education initiatives in Indigenous communities, based on the traditional principles of those nations, would contribute to both our understanding of culture-specific transformative learning and to the aims of the broader Indigenous food sovereignty movement. This proposed retheorization of transformative learning could help to eliminate the implicit colonial underpinnings inherent in the purportedly 'neutral' educational approaches endorsed in the name of equity and social justice.

Food systems education initiatives in Haudenosaunee contexts that incorporate principles from the Kaianerkó:wa (Great Law of Peace) and more recent contributions (Antone, 2013; Mohawk \& Barreiro, 2010; Sheridan \& Longboat, 2006) would, over time, provide the experience necessary to fully articulate an approach to transformative food systems education grounded in Haudenosaunee principles. We are hoping to contribute to a more realized Haudenosaunee approach to transformative food systems education at First Nations Technical Institute, and we hope that others will engage in similar culturally localized, practice-informed theory-building in their respective areas.

Transformative learning theory could also be employed to facilitate a transformation in the way that non-Indigenous learners understand the extent to which Indigenous food systems have been impacted by colonialism and the dominant culture's role in maintaining control over the narratives around food system change. As Sumner (2017) points out, Indigenous "food systems, although crippled by colonization, represent living alternatives to the corporate food regime" (p. vii). Transformative learning in non-Indigenous contexts, particularly that which recognizes the relationality inherent in the more-than-human (such as Barrett et al., 2017; Weber-Pillwax, 2001), could be a valuable way to expand the horizon of possibilities for change in the mainstream food system. Transformative learning in postsecondary food system education could also help non-Indigenous learners to understand how to be good allies to Indigenous peoples involved in the food sovereignty movement. 


\section{Conclusions and Further Research}

The FNTI Indigenous food systems undergraduate degree, currently under development, offers several innovations that could be of interest to food system educators in Indigenous and mainstream contexts. First, we place considerable emphasis on cultural revitalization in the first two years of the program to provide learners with an opportunity to learn and share traditional teachings in a supportive group environment. Second, we will employ (as per standard practice at FNTI) talking circles in the food systems classroom to facilitate the collective learning journey. Third, our curriculum draws on traditional teachings and principles such as the Kaianerkó:wa (Great Law of Peace), ka'nikonhri:io (good mind), and the Kariwiyo (Handsome Lake Code) to reinforce cultural values that support a more egalitarian and relational food system. Fourth, and finally, we are building our curriculum on a foundation of TEK regarding agriculture and wild food harvesting, including experiential learning that incorporates the Three Sisters (corn, beans, and squash) polyculture, traditional approaches to seed germination and pest management, and the planting of heirloom crop varieties (e.g., the Deseronto potato bean, Iroquois white corn, Seneca horn potato, Buffalo Creek squash) in our greenhouse and field sites. In our assessment, transformative learning theory (Mezirow, 2000) has the potential to help Indigenous learners to challenge colonial narratives and could also help to support non-Indigenous allies in mainstream contexts. However, transformative learning theory, grounded in Western ways of knowing, is not sufficient for an authentic decolonized approach to Indigenous food systems education.

This paper presents some of our preliminary ideas regarding the first, to our knowledge, Indigenous food systems undergraduate degree program on Turtle Island. We plan to continue documenting the evolution of our program, and we hope that this paper will inspire other groups to initiate similar programs in Indigenous contexts (e.g., Tribal Colleges in the United States, Indigenous Institutes and other Indigenous postsecondary institutions in Canada, and Indigenous Intercultural Universities in Latin America and the Caribbean), or in mainstream universities that serve Indigenous commu- nities. Further research that would benefit our Indigenous food systems program at FNTI and others involved in decolonizing Indigenous food systems education initiatives at the postsecondary level include:

- Studying the applicability of transformative learning theory and the use of traditional teachings and principles in other Indigenous food system higher education environments would help to create both a body of evidence and principles to support further decolonizing food systems education initiatives, which ideally would lead to more just and healthier communities and food systems;

- Exploring the use of transformative learning theory for supporting non-Indigenous food system allyship could build on the goodwill in the alternative food movement toward Indigenous food systems activists, advocates, and researchers;

- Documenting the long-term implications of our educational model on learners and their communities, both during the four-year degree and after graduation, would help us to serve our learners and their communities more effectively;

- Documenting traditional ecological knowledge (TEK) about specific Haudenosaunee agricultural practices and crop varieties for incorporation into our curriculum would deepen our ability to teach students to revitalize a more fully realized Haudenosaunee food system; and

- Determining how best to prepare and support teachers to deliver a decolonized food systems curriculum in Indigenous contexts would ensure the efficacy of our program and develop a cadre of instructional staff who could share their expertise with their Indigenous and mainstream food system education colleagues in other institutions.

\section{Acknowledgments}

The authors wish to recognize the hard work and thoughtful comments provided by four anonymous reviewers. 


\section{References}

Akwesasne Notes (Ed.). (2005). Basic call to consciousness. Summertown, Tennessee: Native Voices.

Antone, R. (2013). Yukwalihowanabtu yukwanosaunee tsiniyukwaliho:t^ As people of the Longhouse, we honor our way of life tekal^ hsal^ tsiniyukwaliho: $t^{\wedge}$ praise our way of life (Doctoral dissertation). State University of New York, Buffalo.

Barrett, M. J., Harmin, M., Maracle, B., Patterson, M., Thomson, C., Flowers, M., \& Bors, K. (2017). Shifting relations with the more-than-human: Six threshold concepts for transformative sustainability learning, Environmental Education Research, 23(1), 131-143. https://doi.org/10.1080/13504622.2015.1121378

Battiste, M. (Ed.). (2016). Visioning a Mi'kmaw humanities: Indigenizing the academy. Sydney, Nova Scotia: Cape Breton University Press.

Berkes, F., Colding, J., \& Folke, C. (2003). Navigating social-ecological systems: Building resilience for complexity and change. Cambridge, UK: Cambridge University Press

Butler, J. (2004). Undoing gender. New York: Routledge.

Cajete, G. (2000). Native science: Natural laws of interdependence. Santa Fe, New Mexico: Clear Light Publishers.

Castellano, M. B. (2000). Updating Aboriginal traditions of knowledge. In G. J. Sefa Dei, B. L. Hall, \& D. G. Rosenberg (Eds.), Indigenous knowledges in global contexts (pp. 22-26). Toronto: University of Toronto Press.

Chen, Y., Brockner, J., \& Katz, T. (1998). Toward an explanation of cultural differences in in group favoritism: The role of individual versus collective primacy. Journal of Personality and Social Psychology, 75(6), 1490-1502.

https://doi.org/10.1037/0022-3514.75.6.1490

Coté, C. (2016). "Indigenizing" food sovereignty. Revitalizing Indigenous food practices and ecological knowledges in Canada and the United States. Humanities, 5(57), 1-14. https://doi.org/10.3390/h5030057

Coulthard, G. (2014). Red skins, white masks: Rejecting the colonial politics of recognition. Minneapolis: University of Minnesota Press.

Council of Canadian Academies. (2014). Aboriginal food security in northern Canada: An assessment of the state of knowledge. Ottawa: The Expert Panel on the State of Knowledge of Food Security in Northern Canada.

Courtenay, B. C., Merriam, S. B., \& Reeves, P. M. (1998). The centrality of meaning-making in transformational learning: How HIV-positive adults make sense of their lives. Adult Education Quarterly, 48(2), 102-119. https://doi.org/10.1177/074171369804800203

Cranton, P. (2006). Understanding and promoting transformative learning: A guide for educators of adults. San Francisco: JosseyBass.

Culhane, D. (1998). The pleasure of the crown: Anthropology, law, and First Nations. Vancouver: Talonbooks.

Davila, F. \& Dyball, R. (2015). Transforming food systems through food sovereignty: An Australian urban context. Australian Journal of Environmental Education, 31(1), 34-45. https://doi.org/10.1017/aee.2015.14

Dion-Buffalo, Y., \& Mohawk, J. (1999). Daybreak farm and food project seeks revitalization of white corn usage. In G. Cajete (Ed.), A people's ecology: Explorations in sustainable living (pp. 175-195). Santa Fe, New Mexico: Clearlight Publishers.

Dirkx, J. M. (2006). Engaging emotions in adult learning: A Jungian perspective on emotion and transformative learning. New Directions for Adult and Continuing Education, 109, 15-26. https://doi.org/10.1002/ace.204

Ericksen, P. J. (2008). Conceptualizing food systems for global environmental change research. Global Environmental Change, 18(1), 234-245. https://doi.org/10.1016/i.gloenvcha.2007.09.002

Etmanski, C. (2018). Seeds and stories of transformation from the individual to the collective. Journal of Transformative Education, 16(2), 151-167. https://doi.org/10.1177/1541344617696973

Food and Agriculture Organization of the United Nations [FAO]. (1996). World food summit: Rome declaration on world food security and world food summit plan of action. Rome: FAO.

Fleischhacker, S., Vu, M., Ries, A., \& McPhail, A. (2011). Engaging tribal leaders in an American Indian healthy eating project through modified talking circles. Community Health, 34(3), 202-210.

https://doi.org/10.1097/FCH.0b013e31821960bb 
Foran, T., Butler, J. R. A., Williams, L. J., Wanjurra, W. J., Hall, A., Carter, L., \& Carberry, P. S. (2014). Taking complexity in food systems seriously: An interdisciplinary analysis. World Development, 61, 85-101. https://doi.org/10.1016/i.worlddev.2014.03.023

Freire, P. (c. 1970/2012). Pedagogy of the oppressed. New York: Boomsbury.

Hartle, J., Cole, S., Chrisinger, B., \& Gardner, C. (2017). Interdisciplinary food-related academic programs: A 2015 snapshot of the United States landscape. Journal of Agriculture, Food Systems, and Community Development, 7(4), 35-49. https://doi.org/10.5304/jafscd.2017.074.006

Hofstede, G. (1980). Culture's consequences. Beverly Hills, California: SAGE.

Hui, C. H. (1988). Measurement of individualism-collectivism. Journal of Research in Personality, 22(1), 17-36. https://doi.org/10.1016/0092-6566(88)90022-0

Indigenous Institutes Act, S.O. 2017, c. 34, Sched. 20. (2017). Retrieved from https://www.ontario.ca/laws/statute/17i34a

Johansen, B. E, \& Mann, B. A. (Eds.). (2000). Encyclopedia of the Haudenosaunee (Iroquois Confederacy). Westport, Connecticut: Greenwood.

Kholghi, M. K., Bartlett, G., Phillips, M., Salsberg, J., McComber, A. M., \& Macaulay, A. C. (2018). Evaluating an Indigenous health curriculum for diabetes prevention: Engaging the community through talking circles and knowledge translation of results. Family Practice, 35(1), 80-87. https://doi.org/10.1093/fampra/cmx068

Lowe, J., \& Wimbish-Cirilo, R. (2016). The use of talking circles to describe a Native American transcultural caring immersion experience. Journal of Holistic Nursing, 34(3), 280-290. https://doi.org/10.1177/0898010115610020

Luarkie, R. (2017). Research is a pebble in my shoe. In E.S . Huaman \& B. J. Brayboy (Eds.), Indigenous Innovations in Higher Education (pp. 125-141). Rotterdam, The Netherlands: Sense Publishers.

Mehl-Madrona, L., \& Mainguy, B. (2014). Introducing healing circles and talking circles into primary care. The Permanente Journal, 18(2), 4-9. https://doi.org/10.7812/TPP/13-104

Merriam, S. B., \& Ntseane, G. (2008). Transformational learning in Botswana: How culture shapes the process. Adult Education Quarterly, 58(3), 187-193. https://doi.org/10.1177/0741713608314087

Merriam, S., \& Sek Kim, Y. (2008). Non-Western perspectives on learning and knowing. New Directions for Adult and Continuing Education, 2008(119), 71-81. https://doi.org/10.1002/ace.307

Mezirow, J. (1991). Transformative dimensions of adult learning. San Francisco: Jossey Bass.

Mezirow, J. (1994). Understanding transformation theory. Adult Education Quarterly, 44(4), 222-232. https://doi.org/10.1177/074171369404400403

Mezirow, J. (1997). Transformative learning: Theory to practice. In P. Cranton (Ed.), Transformative learning in action: Insights from practice (pp. 5-12). San Francisco: Jossey-Bass.

Mezirow, J. (1998). On critical reflection. Adult Learning Quarterly, 48(3), 185-198. https://doi.org/10.1177/074171369804800305

Mezirow, J. (2000). Learning as transformation: Critical perspectives on a theory in progress. San Francisco: Jossey-Bass.

Mezirow, J. (2006). An overview of transformative learning. In P. Sutherland \& J. Crowther (Eds.), Lifelong learning: Concepts and contexts (pp. 24-38). New York: Routledge.

Mezirow, J. (2009). Transformative learning theory. In J. Mezirow \& E. W. Taylor (Eds), Transformative learning in practise: Insights from community, workplace, and higher education (pp. 18-32). San Francisco: Jossey Bass.

Mohawk, J. (Author), \& Barreiro, J. (Ed.). (2010). Thinking in Indian: A John Mohawk reader. Golden, Colorado: Fulcrum.

Morcom, L. A. (2017). Indigenous holistic education in philosophy and practice, with wampum as a case study. Foro de Educación, 15(23), 121-138. https://doi.org/10.14516/fde.572

Nabigon, H., Hagey, R., Webster, S., \& MacKay, R. (1999). The learning circle as a research method: The trickster and windigo in research. Native Social Work Journal, 2(1), 113-137. Retrieved from https://zone.biblio.laurentian.ca/handle/10219/461 
Ontario Ministry of Education (2009). Grade 1 language: Circle traditions-Talking circle. Aboriginal perspectives: The teacher's toolkit. Ottawa: Ontario Ministry of Education. Retrieved from http://www.edu.gov.on.ca/eng/aboriginal/strategygr01lancircle.pdf

Oyserman, D., Coon, H. M., \& Kemmelmeier, M. (2002). Rethinking individualism and collectivism: Evaluation of theoretical assumptions and meta-analyses. Psychological Bulletin, 128(1), 3-72. https://doi.org/10.1037/0033-2909.128.1.3

Reader, T., \& Dew Johnson, T. (2017). Fishing for change: A pedagogy of native food sovereignty. In C. Etmanski (Ed.), Food leadership: Leadership and adult learning for global food systems transformation (pp. 37-52). Rotterdam, Boston, \& Taipei: Sense Publishers.

Rothe, J. P., Ozegovic, D., \& Carroll, L. J. (2009). Innovation in qualitative interviews: "Sharing Circles" in a First Nations community. Injury Prevention, 15(5), 334-340. https://doi.org/10.1136/ip.2008.021261

Running Wolf, P., \& Rickard, J. A. (2003). Talking circles: A Native American approach to experiential learning. Journal of Multicultural Counselling and Development, 31(1), 39-43. https://doi.org/10.1002/j.2161-1912.2003.tb00529.x

Said, E.W. (1993). Culture and imperialism. New York: Random House.

Salmón, E. (2012). Eating the landscape: American Indian stories of food, identity, and resilience. Tucson: University of Arizona Press.

Santiago-Rivera, A. L., Morse, G. S., Hunt, A., \& Lickers, H. (1998). Building a community- based research partnership: Lessons from the Mohawk nation of Akwesasne. Journal of Community Psychology, 26(2), 163-174. https://doi.org/10.1002/(SICI)1520-6629(199803)26:2<163::AID-JCOP5>3.0.CO;2-Y

Schaaf, G. (1988). From the Great Law of Peace to the Constitution of the United States: A revision of America's democratic roots. American Indian Law Review, 14(2), 323-331. https://doi.org/10.2307/20068293

Schwartz, S. H. (1990). Individualism-collectivism: Critique and proposed refinements. Journal of Cross-Cultural Psychology, 21(2), 139-157. https://doi.org/10.1177/0022022190212001

Sheridan, J., \& Longboat, D. (2006). The Haudenosaunee imagination and the ecology of the sacred. Space and Culture, 9(4), 365-381. https://doi.org/10.1177/1206331206292503

Simmons, D., Bayha, W., Beaulieu, D., Gladu, D., \& Manseau, M. (2012). Aborginal talking circle: Aboriginal perspectives on caribou conservation. Rangifer, 32(2), 17-19. https://doi.org/10.7557/2.32.2.2239

Subnath, M. (2017). Indigenous food insecurity in Canada: An analysis using the 2012 Aboriginal peoples survey (Master's thesis). Wilfred Laurier University, London, Ontario. https://ir.lib.uwo.ca/etd/4459

Sumner, J. (2017). Foreword. In C. Etmanski (Ed.), Food leadership: Leadership and adult learning for global food systems transformation (pp. vii-iix). Rotterdam, Boston, \& Taipei: Sense Publishers.

Tarasuk, V., Mitchell, A., \& Dachner, N. (2016). Household food insecurity in Canada, 2014. Retrieved from http://proof.utoronto.ca

Taylor, E. W. (2007). An update of transformative learning theory: A critical review of the empirical research (19992005). International Journal of Lifelong Education, 26(2), 173-191. https://doi.org/10.1080/02601370701219475

Triandis, H. C. (1995). Individualism and collectivism. Boulder, Colorado: Westview Press.

Umbreit, M. (2003). Talking circles. St. Paul: University of Minnesota Centre for Restorative Justice and Peacemaking.

United Nations. (2007). Declaration on the rights of indigenous peoples. Retrieved from https://www.un.org/development/ desa/indigenouspeoples/wp-content/uploads/sites/19/2018/11/UNDRIP E web.pdf

wa Thiong'o, N. (1994). Decolonising the mind: The politics of language in African literature. Harare: Zimbabwe Publishing House.

Weber-Pillwax, C. (2001). What is Indigenous research? Canadian Journal of Native Education, 25(2), $166-174$.

Wilbur, J. R., Wilbur, M., Tlanusta Garrett, M., \& Yuhas, M. (2001) Talking circles: Listen, or your tongue will make you deaf. Journal for Specialists in Group Work, 26(4), 368-384. https://doi.org/10.1080/01933920108413785

Wilson, S. (2001). What is an Indigenous research methodology? Canadian Journal of Native Education, 25(2), $175-79$.

Wilson, S. (2008). Research is ceremony: Indigenous research methods. Black Point, Nova Scotia: Fernwood. 
Winters, A. (n.d.) Using talking circles in the classroom. Normal, Illinois: Heartland Community College. Retrieved from https://www.heartland.edu/documents/idc/talkingCircleClassroom.pdf

Yamagishi, T. (1988). Exit from the group and in individualistic solution to the free rider problem in the United States and Japan. Journal of Experimental Social Psychology, 24(6), 530-542. https://doi.org/10.1016/0022-1031(88)90051-0

Zwicky, J. (2014). Lyric philosophy (2 ${ }^{\text {nd }}$ Ed.). Kentville, Nova Scotia: Gaspereau Press. 